\title{
Retraction Note to: Nicardipine enhances diaphragmatic fatigue
}

\author{
Yoshitaka Fujii, MD · Hidenori Toyooka, MD • \\ Keisuke Amaha, MD
}

Published online: 27 November 2012

(c) Canadian Anesthesiologists' Society 2012

\section{Retraction Note to: Can J Anaesth 1994; 41: 435-9 DOI 10.1007/BF03009869}

To our readers:

Further to the Expression of Concern* posted online on March $13^{\text {th }}, 2012$, it is with considerable regret that the Canadian Journal of Anesthesia hereby retracts the above-cited article by Dr. Yoshitaka Fujii as a result of: (1) overwhelming evidence of fabrication relating to the fact that the distributions of many variables reported by Dr. Fujii in these studies are exceedingly unlikely; ${ }^{1,2}$ and (2) the inability of Dr. Fujii's institution to attest to the integrity of the study and/or the data conducted under its auspices, as set out in the Joint Editors-in-Chief Request for Determination of April 9, 2012. ${ }^{\dagger}$ We extend our sincere appreciation to Toride Kyodo General Hospital for their review of the status of Dr. Fujii's research and to the investigating committee for their review of his research findings.

Donald R. Miller, MD

Editor-in-Chief

Canadian Journal of Anesthesia

e-mail: cja_office@cas.ca
À nos lecteurs:

Faisant suite à l'Énoncé de préoccupations* publiée en ligne le 13 mars 2012, c'est avec un immense regret que le Journal canadien d'anesthésie réfute et retire par la présente l'article du Dr Yoshitaka Fujii cité ci-dessus pour les raisons suivantes: (1) la preuve accablante de fabrication de données constituée par le fait que la distribution des nombreuses variables décrites par le Dr Fujii dans ces études est excessivement improbable; ${ }^{1,2}$ et (2) l'incapacité dans laquelle se trouve l'institution où travaille le Dr Fujii d'attester l'intégrité de l'étude et/ou des données menées sous ses auspices, tel qu'établi dans la demande conjointe des Rédacteurs en chef aux fins de décision du 9 avril 2012. ${ }^{\dagger}$ Nous tenons à exprimer toute notre gratitude à Toride Kyodo General Hospital pour leur analyse du statut des recherches du Dr Fujii et au comité d'enquête pour son analyse des résultats de cette recherche.

Donald R. Miller, MD

Rédacteur en chef

Journal canadien d'anesthésie

courriel: cja_office@cas.ca

\section{References}

1. Carlisle $J B$. The analysis of 168 randomised controlled trials to test data integrity. Anaesthesia 2012; 67: 521-37.

2. Kranke P, Apfel CC, Roewer N. Reported data on granisetron and postoperative nausea and vomiting by Fujii et al. are incredibly nice! Anesth Analg 2000; 90: 1004-7.

\footnotetext{
* http://www.springer.com/medicine/anesthesiology/journal/12630.

${ }^{\dagger} \mathrm{http}: / /$ www.aaeditor.org/Fujii_Joint_EIC_Stmt.pdf (accessed September 2012).
} 